\title{
High Corrosion Resistant Ni-Based Glassy Alloys in Boiling Nitric Acid Solutions
}

\author{
C. L. Qin ${ }^{1, *}$, K. Asami ${ }^{2}$, H. Kimura ${ }^{2}$, W. Zhang ${ }^{2}$, D. V. Louzguine ${ }^{1}$ and A. Inoue ${ }^{1}$ \\ ${ }^{1}$ WPI Advanced Institute for Materials Research, Tohoku University, Sendai 980-8577, Japan \\ ${ }^{2}$ Institute for Materials Research, Tohoku University, Sendai 980-8577, Japan
}

The $\mathrm{Ni}_{57} \mathrm{Nb}_{19} \mathrm{Zr}_{19} \mathrm{Ta}_{5}$ glassy alloy possesses high corrosion resistance in severe environments, i.e. boiling $6 \mathrm{~N}$ HNO 3 and $6 \mathrm{~N}$ $\mathrm{HNO}_{3}+5 \mathrm{~g} / 1 \mathrm{Cr}^{6+}$ solutions. In both solutions, the corrosion resistance of the $\mathrm{Ni}_{57} \mathrm{Nb}_{19} \mathrm{Zr}_{19} \mathrm{Ta}_{5}$ alloy is much better than that of NAR-310Nb stainless steel which is developed as nitric acid corrosion resistant stainless steel. XPS analysis reveals that the high corrosion resistance of the Ni-based glassy alloys is due to the formation of the highly protective passive film composed exclusively of $\mathrm{Nb}^{5+}$ and $\mathrm{Ta}^{5+} \mathrm{cations}$ after immersion in the solution without $\mathrm{Cr}^{6+}$ ions, and $\mathrm{Nb}^{5+}, \mathrm{Ta}^{5+}$ and $\mathrm{Cr}^{3+}$ cations after immersion in the solution with $\mathrm{Cr}^{6+}$ ions. [doi:10.2320/matertrans.ME200814]

(Received December 9, 2008; Accepted March 31, 2009; Published May 20, 2009)

Keywords: glassy alloys, corrosion resistance, nitric acid, polarization curves, X-ray photoelectron spectroscopy (XPS) analysis

\section{Introduction}

Since extremely corrosion resistant $\mathrm{Fe}-\mathrm{Cr}$-metalloid amorphous alloys were found in the middle of $1970 \mathrm{~s},{ }^{1)}$ one of the important features of amorphous alloys, i.e. high corrosion resistance, has been discovered. The absence of crystalline defects and the chemically homogeneous single-phase nature of amorphous alloys lead to the formation of a uniform passive film and hence are responsible for high corrosion resistance. Since then, various types of high corrosion resistant amorphous, glassy alloys and bulk metallic glasses have been developed by sputter deposition, melt spinning and copper-mold casting methods, as exemplified for $\mathrm{Ni}-\mathrm{Cr}$ metalloid, ${ }^{2,3)} \mathrm{Ni}$-valve metal, ${ }^{4,5)}(\mathrm{Cr}, \mathrm{Mo}, \mathrm{W})$-valve metal, ${ }^{6-8)}$ $\mathrm{Fe}-\mathrm{Cr}-\mathrm{Mo}-\mathrm{P}-\mathrm{C}^{9,10)}$ alloy systems, which possess superior corrosion resistance in concentrated hydrochloric acid solutions. However, there have been no data about corrosion resistance of glassy alloys in boiling nitric acid solutions. For nuclear fuel reprocessing applications, reprocessing of spent nuclear fuel involves use of nitric acid of high concentrations and high temperatures. The boiling nitric acid also contains small amounts of other ions such as $\mathrm{Cr}^{6+}, \mathrm{Ag}^{2+}, \mathrm{Ce}^{4+}$, $\mathrm{Cr}_{2} \mathrm{O}_{7}{ }^{2-}$ etc. Therefore, the materials for fabrication of such reprocessing plant equipment should exhibit excellent corrosion resistance. Conventional materials do not have enough corrosion resistance such as AISI 304L stainless steel ${ }^{11)}$ and even nitric acid grade stainless steel Uranus 65. ${ }^{12}$ )

With the aim of searching for high corrosion resistant glassy alloys in severe environments, i.e. boiling $6 \mathrm{~N} \mathrm{HNO}_{3}$ solutions with and without $5 \mathrm{~g} / \mathrm{l} \mathrm{Cr}^{6+}$, for nuclear fuel reprocessing applications, glass alloys selection is very important. Among various types of glassy alloys developed so far, the $\mathrm{Ni}_{60} \mathrm{Nb}_{20} \mathrm{Zr}_{20}$ glassy alloys ${ }^{13)}$ chosen as a promising candidate for nuclear fuel reprocessing applications for three reasons: (1) The alloy possesses good mechanical properties and a large supercooled liquid region of $51 \mathrm{~K}$. In supercooled liquid region, it can be fabricated into intricate shapes with a high level of dimensional accuracy. (2) The alloy can be formed in a wide ribbon size of a width of $50 \mathrm{~mm}$ and a thickness of $25 \mu \mathrm{m}$. (3) The $20 \mathrm{at} \% \mathrm{Nb}$ content in alloy could

*Corresponding author, E-mail: clqin@wpi-aimr.tohoku.ac.jp provide a strong passivating ability. Furthermore, due to higher corrosion resistance of Ta element than that of $\mathrm{Nb}$ element, ${ }^{14,15)}$ the addition of Ta to the $\mathrm{Ni}-\mathrm{Nb}-\mathrm{Zr}$ glassy alloy is expected to improve the corrosion resistance in such severe environments. So, the present work aims to investigate the corrosion behavior of the $\mathrm{Ni}-\mathrm{Nb}-\mathrm{Zr}-\mathrm{Ta}$ glassy alloys in boiling $\mathrm{HNO}_{3}$ solutions. X-ray photoelectron spectroscopy (XPS) and angle-resolved X-ray photoelectron spectroscopy (ARXPS) were performed to elucidate the origin of the high corrosion resistance by surface characterization.

\section{Experimental}

The alloy ingots of $\mathrm{Ni}-\mathrm{Nb}-\mathrm{Zr}$-Ta were prepared by arcmelting mixtures of pure metals in an argon atmosphere. Ribbon samples were fabricated by melt spinning. The glassy single structure of the melt-spun ribbon samples was confirmed by X-ray diffraction using $\mathrm{Cu} \mathrm{K} \alpha$ radiation.

Prior to immersion and electrochemical measurements, the specimens were polished mechanically with $\mathrm{SiC}$ paper up to grit 1500 in cyclohexane, degreased in acetone, washed in distilled water, dried in air, and further exposed to air for $24 \mathrm{~h}$ for good reproducibility. The corrosion rates were evaluated from the weight loss after immersion for 2 weeks in boiling $6 \mathrm{~N} \mathrm{HNO}_{3}$ solutions with and without $5 \mathrm{~g} / 1 \mathrm{Cr}^{6+}$. Three specimens for each alloy in the same solution were examined for the weight loss test. The average value was used for corrosion rate estimation. Electrochemical measurements were conducted in a three-electrode cell using a platinum counter electrode and an $\mathrm{Ag} / \mathrm{AgCl}$ reference electrode. Potentiodynamic polarization curves were measured at a potential sweep rate of $50 \mathrm{mV} \cdot \mathrm{min}^{-1}$ after open-circuit immersion for about $20 \mathrm{~min}$ when the open-circuit potential became almost steady.

For surface characterization, X-ray photoelectron spectroscopy (XPS) and angle-resolved X-ray photoelectron spectroscopy (ARXPS) measurements were utilized by means of a SSI SSX-100 photoelectron spectrometer with monochromatized $\mathrm{Al} \mathrm{K} \alpha$ excitation $(\mathrm{h} v=1486.6 \mathrm{eV})$ for the melt-spun ribbon samples before and after immersion for $336 \mathrm{~h}$ in boiling $6 \mathrm{~N} \mathrm{HNO}_{3}$ solutions with and without $5 \mathrm{~g} / 1$ $\mathrm{Cr}^{6+}$. X-ray photoelectron spectra were measured at different 


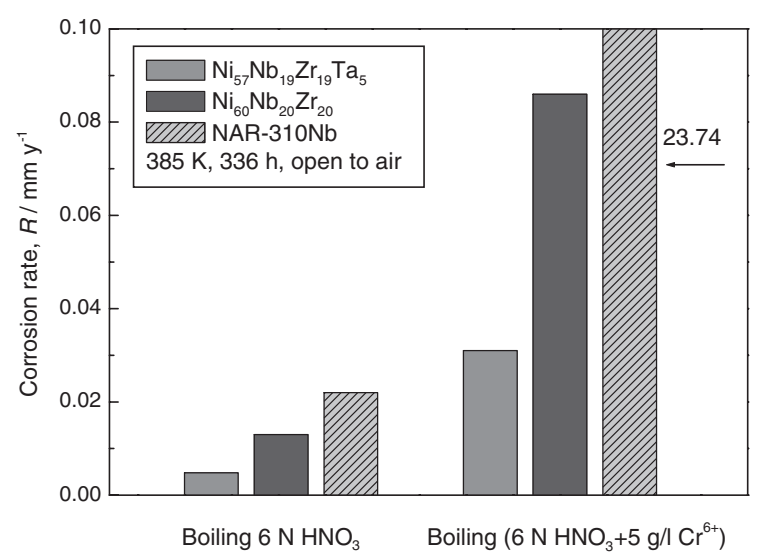

Fig. 1 Average corrosion rates of the Ni-based glassy alloys and NAR$310 \mathrm{Nb}$ stainless steel in boiling $6 \mathrm{~N} \mathrm{HNO}_{3}$ and boiling $\left(6 \mathrm{~N} \mathrm{HNO}_{3}+5 \mathrm{~g} / 1\right.$ $\mathrm{Cr}^{6+}$ ) solutions at $385 \mathrm{~K}$ open to air.

take-off angles $\left(12,35\right.$ and $\left.90^{\circ}\right)$ with respect to the plane of the sample, in order to observe the outer and inner layers of the passive film formed on the alloy. The composition of the surface film and the composition of the underlying alloy surface were quantitatively determined with a previously proposed method using the integrated intensities of photoelectrons under the assumption of a three-layer model of an outmost contaminant hydrocarbon layer of uniform thickness, a surface film of uniform thickness and an underlying alloy surface of infinite thickness as regards x-ray-photoelectrons. ${ }^{16,17)}$

\section{Results and Discussion}

We firstly chose the $\mathrm{Ni}_{60} \mathrm{Nb}_{20} \mathrm{Zr}_{20}$ and $\mathrm{Ni}_{57} \mathrm{Nb}_{19} \mathrm{Zr}_{19} \mathrm{Ta}_{5}$ glassy alloys to measure the corrosion rates in boiling $6 \mathrm{~N}$ $\mathrm{HNO}_{3}$ solutions with and without $5 \mathrm{~g} / 1 \mathrm{Cr}^{6+}$ for 2 weeks. It was confirmed that all the melt-spun ribbon samples were completely a single phase glassy structure. Figure 1 shows the average corrosion rates of the Ni-based glassy

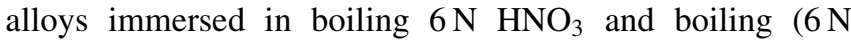
$\mathrm{HNO}_{3}+5 \mathrm{~g} / 1 \mathrm{Cr}^{6+}$ ) solutions, open to air for 2 weeks. The stainless steel NAR-310Nb which is known for high corrosion resistance in nitric acid is also examined in the same solutions for comparison. The temperature in both solutions is as high as about $385 \mathrm{~K}$. The corrosion rates of the $\mathrm{Ni}_{60} \mathrm{Nb}_{20} \mathrm{Zr}_{20}$ alloy are about $0.013 \mathrm{~mm} \cdot$ year $^{-1}$ in $6 \mathrm{~N} \mathrm{HNO}_{3}$ and increases to $0.086 \mathrm{~mm} \cdot \mathrm{year}^{-1}$ in $\mathrm{Cr}^{6+}$ ions containing solution. Meanwhile, after immersion in boiling $6 \mathrm{~N} \mathrm{HNO}_{3}$ solution for 2 weeks, the $\mathrm{Ni}_{57} \mathrm{Nb}_{19} \mathrm{Zr}_{19} \mathrm{Ta}_{5}$ glassy alloy still maintains a metallic luster and displays a high corrosion resistance. Its corrosion rate is about $0.0048 \mathrm{~mm} \cdot$ year $^{-1}$, which is about one order of magnitude lower than those of the $\mathrm{Ni}_{60} \mathrm{Nb}_{20} \mathrm{Zr}_{20}$ alloy and NAR-310Nb stainless steel. In boiling $\mathrm{Cr}^{6+}$ containing solution, the corrosion rate is about $0.031 \mathrm{~mm} \cdot$ year $^{-1}$ for the $\mathrm{Ni}_{57} \mathrm{Nb}_{19} \mathrm{Zr}_{19} \mathrm{Ta}_{5}$ alloy, whereas NAR-310Nb stainless steel dissolves completely within 44 hours, which corresponds to a very high corrosion rate of $23.74 \mathrm{~mm} \cdot$ year $^{-1}$. These facts clearly indicate the superiority of the $\mathrm{Ni}_{57} \mathrm{Nb}_{19} \mathrm{Zr}_{19} \mathrm{Ta}_{5}$ glassy alloy. Moreover, it is also found that the corrosion resistance of the $\mathrm{Ni}_{57} \mathrm{Nb}_{19} \mathrm{Zr}_{19} \mathrm{Ta}_{5}$ glassy alloy is markedly enhanced in both solutions as

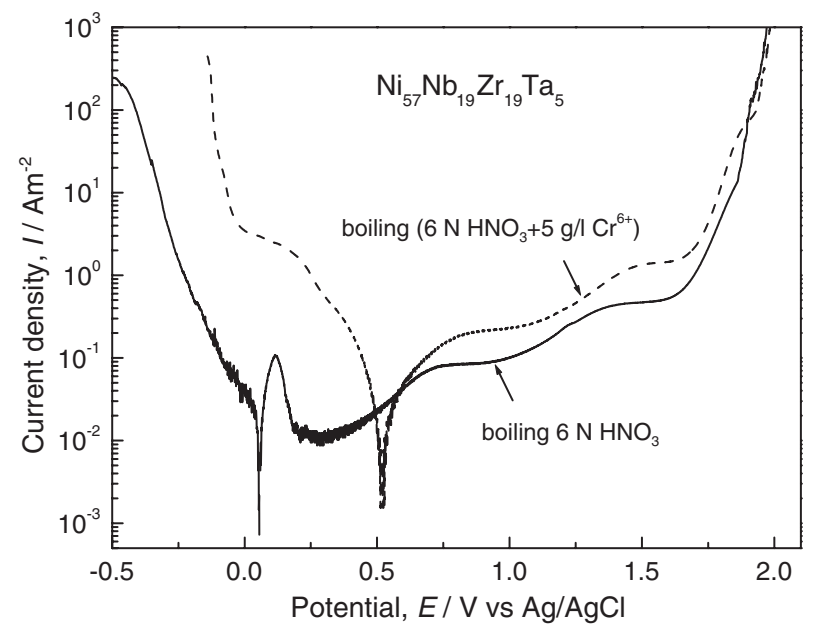

Fig. 2 Potentiodynamic polarization curves of the $\mathrm{Ni}_{57} \mathrm{Nb}_{19} \mathrm{Zr}_{19} \mathrm{Ta}_{5}$ glassy alloy in boiling $6 \mathrm{~N} \mathrm{HNO}_{3}$ solutions with and without $\mathrm{Cr}^{6+}$ ions at $385 \mathrm{~K}$ open to air.

compared to that of the Ta-free $\mathrm{Ni}_{60} \mathrm{Nb}_{20} \mathrm{Zr}_{20}$ glassy alloy, indicating the addition of 5 at $\%$ Ta is effective in improving the corrosion resistance in such severe environments. Therefore, it can be concluded that the Ta-containing Ni-based glassy alloy exhibits high corrosion resistance and its corrosion resistance is much higher than that of NAR$310 \mathrm{Nb}$ stainless steel in nitric acids of high concentration at high temperature. Next, we focus on the $\mathrm{Ni}_{57} \mathrm{Nb}_{19} \mathrm{Zr}_{19} \mathrm{Ta}_{5}$ glassy alloy to further investigate the electrochemical properties and surface-related chemical characteristics of the alloy immersed in boiling nitric acid solutions.

Figure 2 shows the polarization curves of the $\mathrm{Ni}_{57} \mathrm{Nb}_{19}$ $\mathrm{Zr}_{19} \mathrm{Ta}_{5}$ glassy alloy in boiling $6 \mathrm{~N} \mathrm{HNO}_{3}$ solutions with and without $\mathrm{Cr}^{6+}$ ions, open to air. The alloy begins with a small active dissolution, followed by a passivation process with a low passive current density of the order of $10^{-2} \mathrm{Am}^{-2}$ in boiling $6 \mathrm{~N} \mathrm{HNO}_{3}$ at a high temperature of around $385 \mathrm{~K}$, indicating high corrosion resistance of this alloy. On the other hand, in boiling $\left(6 \mathrm{~N} \mathrm{HNO}_{3}+5 \mathrm{~g} / 1 \mathrm{Cr}^{6+}\right)$ solution, spontaneous passivation takes place for the alloy. However, its anodic passive current density of the alloy is higher than that in the solution without $\mathrm{Cr}^{6+}$ ions, which is in accord with the result of corrosion rates test. The alloy in $\mathrm{Cr}^{6+}$ containing solution shows a very noble open circuit potential. It can be simply explained by the reduction of $\mathrm{Cr}^{6+}$ ions. The higher cathodic reaction in the $\mathrm{Cr}^{6+}$ ions containing solution pushes up the immersion potential towards to the positive direction, which is the reason why the presence of $\mathrm{Cr}^{6+}$ ions accelerates corrosion rates of the alloys.

In order to elucidate the origin of the high corrosion resistance of Ta-containing Ni-based glassy alloy, XPS measurements were performed to clarify the surface composition together with their chemical states of the $\mathrm{Ni}_{57} \mathrm{Nb}_{19} \mathrm{Zr}_{19} \mathrm{Ta}_{5}$ specimens as-polished mechanically or immersed for 2 weeks in boiling $6 \mathrm{~N} \mathrm{HNO}_{3}$ and boiling $\left(6 \mathrm{~N} \mathrm{HNO}_{3}+5 \mathrm{~g} / 1 \mathrm{Cr}^{6+}\right)$ solutions. The XPS spectra of the specimens over a wide binding energy region exhibited peaks of Ni 2p, Nb 3d, Zr 3d, Ta 4f, Cr 2p, O 1s, C 1s etc. The $\mathrm{C}$ 1s peaks arose from a contaminant hydrocarbon layer covering the top surface of the specimen. The $\mathrm{O} 1 \mathrm{~s}$ spectrum 


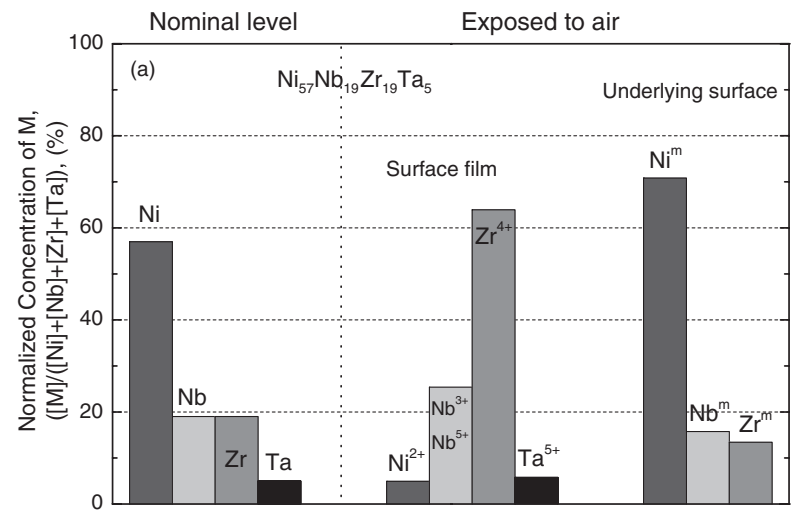

Surface film after immersion

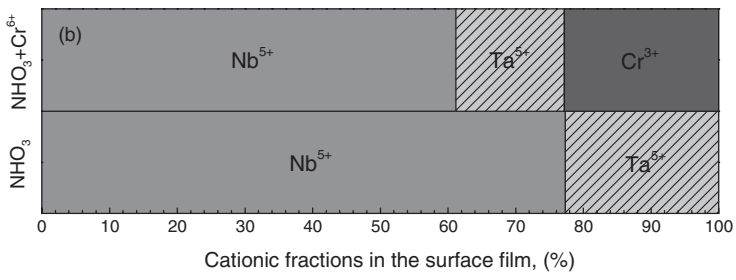

Fig. 3 The cationic fraction of elements in the surface film and the atomic fraction of elements in the underlying alloy just below the surface film for the $\mathrm{Ni}_{57} \mathrm{Nb}_{19} \mathrm{Zr}_{19} \mathrm{Ta}_{5}$ alloy (a) exposed to air and (b) immersed in boiling $6 \mathrm{~N} \mathrm{HNO}_{3}$ and boiling $\left(6 \mathrm{~N} \mathrm{HNO}_{3}+5 \mathrm{~g} / 1 \mathrm{Cr}^{6+}\right)$ solutions for 2 weeks after mechanical polishing.

consisted of peaks originating from oxygen in metal-O-metal bond, metal-OH bond and bound water. It is worth noting that the $\mathrm{Cr} 2 \mathrm{p}$ spectrum for the alloy immersed in $\mathrm{Cr}^{6+}$ containing solution for 2 weeks consists of two peaks at 577.8 and $587.5 \mathrm{eV}$, which are related to $\mathrm{Cr} 2 \mathrm{p}$ electrons of $\mathrm{Cr}^{3+}$ ions in the surface film. ${ }^{18)}$ No peak corresponding to $\mathrm{Cr}^{6+}$ ions was found. The spectrum peaks from alloy constituents were composed of peaks corresponding to their oxidized states in a surface film and the metallic states in an underlying alloy surface. However, on the other specimens after immersion in the both solutions, those peaks showed only oxidic peaks because of the surface films on the specimens were much thicker than the escape depths of photoelectrons.

Figure 3 shows the cationic fraction of element in the surface film $\left(\left[\mathrm{M}^{\mathrm{ox}}\right] /\left[\mathrm{Ni}^{\mathrm{ox}}\right]+\left[\mathrm{Nb}^{\mathrm{ox}}\right]+\left[\mathrm{Zr}^{\mathrm{ox}}\right]+\left[\mathrm{Ta}^{\mathrm{ox}}\right]\right)$ and the atomic fraction of elements in the underlying alloy surface just below the surface film $\left(\left[\mathrm{M}^{\mathrm{m}}\right] /\left[\mathrm{Ni}^{\mathrm{m}}\right]+\left[\mathrm{Nb}^{\mathrm{m}}\right]+\right.$ $\left.\left[\mathrm{Zr}^{\mathrm{m}}\right]+\left[\mathrm{Ta}^{\mathrm{m}}\right]\right)$ for the $\mathrm{Ni}_{57} \mathrm{Nb}_{19} \mathrm{Zr}_{19} \mathrm{Ta}_{5}$ alloy (a) exposed to air and (b) immersed in boiling $6 \mathrm{~N} \mathrm{HNO}_{3}$ and boiling $(6 \mathrm{~N}$ $\mathrm{HNO}_{3}+5 \mathrm{~g} / 1 \mathrm{Cr}^{6+}$ ) solutions for 2 weeks after mechanical polishing. [M] denotes a molar concentration percent of the alloy constituent elements. In Fig. 3(a), when the alloy is exposed to air after mechanical polishing, $\mathrm{Zr}$ and $\mathrm{Nb}$ cations are largely enriched in the surface film, whereas $\mathrm{Ni}$ cations are deficient. In addition, the concentration of Ta cations slightly increases with respect to the alloy composition. This fact reveals that the preferential oxidation of $\mathrm{Zr}$ and $\mathrm{Nb}$ occurs during air exposure whereas $\mathrm{Ni}$ is scarcely oxidized. The major cation in the as-polished surface film is $\mathrm{Zr}^{4+}$ and followed by $\mathrm{Nb}^{5+}\left(\mathrm{Nb}^{3+}\right), \mathrm{Ta}^{5+}$ and $\mathrm{Ni}^{2+}$. By contrast, metallic $\mathrm{Ni}$ is significantly concentrated in the underlying surface just below the surface film by air exposure, while the contents of $\mathrm{Nb}$ and $\mathrm{Zr}$ metal decrease. Meanwhile, we could not detect Ta metal in the underlying surface. When the specimen was immersed in boiling $6 \mathrm{~N} \mathrm{HNO}_{3}$ solution, it is interesting to find that the cations of the passive surface are composed exclusively of $\mathrm{Nb}^{5+}$ and $\mathrm{Ta}^{5+}$. This result revealed that the air-formed film was not stable in boiling $6 \mathrm{~N} \mathrm{HNO}_{3}$ and converted to the stable passive film that consisted only of $\mathrm{Nb}$ and $\mathrm{Ta}$ passivating elements, as a consequence of preferential dissolution of $\mathrm{Ni}$ and $\mathrm{Zr}$ elements during the immersion. In general, $\mathrm{Ti}, \mathrm{Zr}, \mathrm{Nb}$ and $\mathrm{Ta}$ alloying elements are all high corrosion resistant elements and show strong passivating ability. But in such severe environments, Ta and $\mathrm{Nb}$ elements demonstrate their strong passivating ability, whereas $\mathrm{Zr}$ and $\mathrm{Ti}$ elements show active dissolution behavior. After immersion in $\mathrm{Cr}^{6+}$ containing solution, we also found a certain amounts of $\mathrm{Cr}^{3+}$ ions in the surface which are from the solution, in addition to $\mathrm{Nb}$ and Ta cations. Consequently, the formation of the highly protective surface film composed exclusively of $\mathrm{Nb}^{5+}, \mathrm{Ta}^{5+}$ or $\mathrm{Cr}^{3+}$, is responsible for the high corrosion resistance for the present alloy in such severe environments. Combined the corrosion rates in two solutions presented in Fig. 1 and XPS results, it can be seen that the passive surface film consisting only of $\mathrm{Nb}$ and $\mathrm{Ta}$ cations after immersion in the solution without $\mathrm{Cr}^{6+}$ ions is more protective, stable and resistant to corrosion in comparison with that consisting of $\mathrm{Nb}$, $\mathrm{Ta}$ and $\mathrm{Cr}$ cations after immersion in the solution with $\mathrm{Cr}^{6+}$ ions. Actually, the $\mathrm{Cr}^{3+}$ is also one of the corrosion resistance enhancing cations. For example, the sputter-deposited Ta-Cr alloys ${ }^{19,20)}$ which its surface film consists of $\mathrm{Cr}^{3+}$ and $\mathrm{Ta}^{5+}$ cations have extraordinarily high corrosion resistance; they have higher corrosion resistance than those of pure Ta and $\mathrm{Cr}$ metals. However, the $\mathrm{Cr}^{3+}$ cations in the surface film formed in the solution containing $\mathrm{Cr}^{6+}$ ions is just deposited from the solution and it might be not completely incorporated in the surface film. Thus, the passive surface film consisting only of $\mathrm{Nb}$ and Ta cations is more dense and stable to corrosion in comparison with that consisting of $\mathrm{Nb}$, Ta and $\mathrm{Cr}$ cations.

On the other hand, XPS measurements were also carried out for Ta-free $\mathrm{Ni}_{60} \mathrm{Nb}_{20} \mathrm{Zr}_{20}$ glassy alloy. The passive films on the $\mathrm{Ni}_{60} \mathrm{Nb}_{20} \mathrm{Zr}_{20}$ glassy alloy consisted only of $\mathrm{Nb}^{5+}$ cations after immersion in boiling $6 \mathrm{~N} \mathrm{HNO}_{3}$ solution, and $\mathrm{Nb}^{5+}$ and $\mathrm{Cr}^{3+}$ cations after immersion in boiling $(6 \mathrm{~N}$ $\left.\mathrm{HNO}_{3}+5 \mathrm{~g} / 1 \mathrm{Cr}^{6+}\right)$ solution. The big difference is the passive surface films for Ta-containing $\mathrm{Ni}_{57} \mathrm{Nb}_{19} \mathrm{Zr}_{20} \mathrm{Ta}_{5}$ alloy contains a certain amounts of Ta cations, in addition to $\mathrm{Nb}$ or $\mathrm{Cr}$ cations. From the corrosion point of view, it is well known that Ta element for enhancing the corrosion resistance is better than $\mathrm{Nb}$ element. ${ }^{14,15)}$ Therefore, it can be said that the protective quality of the surface films is improved by the addition of Ta element, and hence better corrosion resistance.

To determine the in-depth distribution of elements in the passive films on the $\mathrm{Ni}_{57} \mathrm{Nb}_{19} \mathrm{Zr}_{19} \mathrm{Ta}_{5}$ alloy, angle-resolved XPS measurements (ARXPS) were performed. The Al K $\alpha$ $\mathrm{X}$-ray irradiation on specimen caused the excitation of the photoelectrons. The angle between the horizontal to the surface of the specimen and the direction of photoelectron to the detector was photoelectron take-off angle $(\theta)$. The change in the take-off angle, $\theta$, of the photo-electrons from low angle to high angle gives information from the upper-most surface to the interior of the surface. In fact, the depth from the 

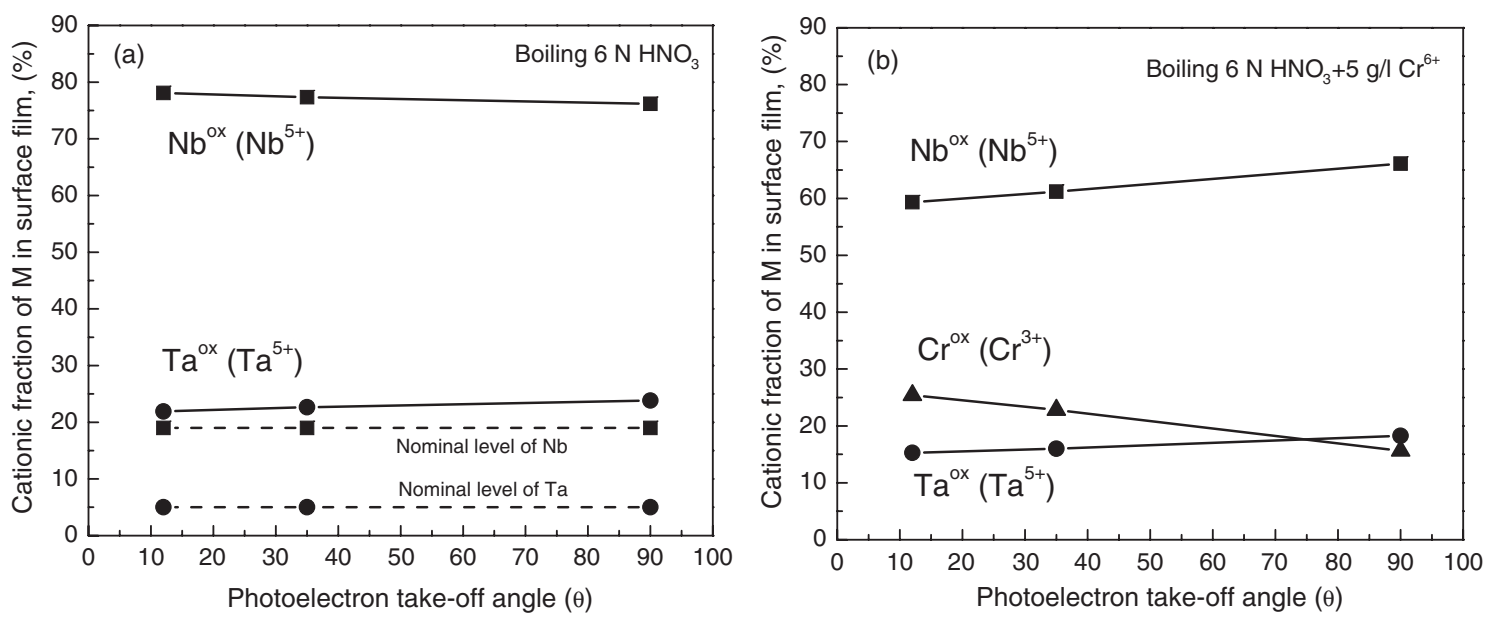

Fig. 4 The change in cationic fraction of elements in the surface film for the $\mathrm{Ni}_{57} \mathrm{Nb}_{19} \mathrm{Zr}_{19} \mathrm{Ta}_{5}$ alloy after immersion for 2 weeks in (a) boiling $6 \mathrm{~N} \mathrm{HNO}_{3}$ and (b) boiling $6 \mathrm{~N} \mathrm{HNO}_{3}+5 \mathrm{~g} / 1 \mathrm{Cr}^{6+}$ as a function of take-off angle of photoelectrons.

surface is proportional to $\sin \theta$. Figure 4 shows the change in the cationic fraction of elements in the surface film for the $\mathrm{Ni}_{57} \mathrm{Nb}_{19} \mathrm{Zr}_{19} \mathrm{Ta}_{5}$ alloy after immersion for 2 weeks in (a) boiling $6 \mathrm{~N} \mathrm{HNO}_{3}$ and (b) boiling $6 \mathrm{~N} \mathrm{HNO}_{3}+5 \mathrm{~g} / 1 \mathrm{Cr}^{6+}$ as a function of take-off angle of photoelectrons. In Fig. 4(a), the contents of the $\mathrm{Nb}^{5+}$ and $\mathrm{Ta}^{5+}$ cations almost do not change with increasing take-off angle of photoelectrons. This fact indicates that the $\mathrm{Nb}^{5+}$ and $\mathrm{Ta}^{5+}$ cations are distributed homogeneously through the depth of the passive films for the $\mathrm{Ni}_{57} \mathrm{Nb}_{19} \mathrm{Zr}_{19} \mathrm{Ta}_{5}$ alloy immersed in boiling $6 \mathrm{~N} \mathrm{HNO}_{3}$ solution, which means the spontaneous passive film is compositionally homogeneous. On the contrary, in the passive film formed in $6 \mathrm{~N} \mathrm{HNO}_{3}+5 \mathrm{~g} / 1 \mathrm{Cr}^{6+}$ solution (Fig. 4(b)), there is a compositional gradient. The contents of $\mathrm{Nb}^{5+}$ and $\mathrm{Ta}^{5+}$ cations increase gradually with an increase in the photoelectron take-off angle, while that of $\mathrm{Cr}^{3+}$ cations decreases. The result reveals that the higher $\mathrm{Cr}^{3+}$ ions concentration in the outer part of the film compared with the inner part of the film. Reverse is seen for $\mathrm{Nb}^{5+}$ and $\mathrm{Ta}^{5+}$ contents. As $\mathrm{Cr}^{3+}$ ions result from the reduction of $\mathrm{Cr}^{6+}$ ions in the solutions, it is reasonable that the concentration of $\mathrm{Cr}^{3+}$ ions in the outer region of the passive film is higher than that in the inner region of the passive film.

\section{Conclusions}

The Ta-containing $\mathrm{Ni}_{57} \mathrm{Nb}_{19} \mathrm{Zr}_{19} \mathrm{Ta}_{5}$ glassy alloy exhibits high corrosion resistance in severe environments, i.e. boiling $6 \mathrm{~N} \mathrm{HNO}_{3}$ and $6 \mathrm{~N} \mathrm{HNO}_{3}+5 \mathrm{~g} / 1 \mathrm{Cr}^{6+}$ solutions. In both solutions, the corrosion resistance of the present glassy alloy is much better than that of NAR-310Nb stainless steel, which may be of great potential for nuclear fuel reprocessing applications. The high corrosion resistance of the Tacontaining Ni-based glassy alloy is attributable to the formation of the highly protective passive film composed exclusively of $\mathrm{Nb}^{5+}$ and $\mathrm{Ta}^{5+}$ cations after immersion in the solution without $\mathrm{Cr}^{6+}$ ions, and $\mathrm{Nb}^{5+}, \mathrm{Ta}^{5+}$ and $\mathrm{Cr}^{3+}$ cations after immersion in the solution with $\mathrm{Cr}^{6+}$ ions. According to ARXPS analysis, both $\mathrm{Nb}^{5+}$ and $\mathrm{Ta}^{5+}$ cations are distributed uniformly in depth of the passive film for alloy immersed

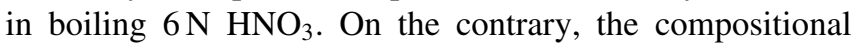

gradients are observed in the passive film formed in $6 \mathrm{~N}$ $\mathrm{HNO}_{3}+5 \mathrm{~g} / 1 \mathrm{Cr}^{6+}$ solution; $\mathrm{Cr}^{3+}$ cations are concentrated in the exterior of the passive film while the contents of $\mathrm{Nb}^{5+}$ and $\mathrm{Ta}^{5+}$ cations increase in the interior of the film.

\section{REFERENCES}

1) M. Naka, K. Hashimoto and T. Masumoto: J. Jpn. Inst. Met. 38 (1974) 835-841.

2) H. Habazaki, T. Sato, A. Kawashima, K. Asami and K. Hashimoto: Mater. Sci. Eng. A 304-306 (2001) 696-700.

3) H. Katagiri, S. Meguro, M. Yamasaki, H. Habazaki, T. Sato, A. Kawashima, K. Asami and K. Hashimoto: Corros. Sci. 43 (2001) 171182.

4) C. L. Qin, W. Zhang, H. Nakata, H. Kimura, K. Asami and A. Inoue: Mater. Trans. 46 (2005) 858-862.

5) A. Inoue, W. Zhang and T. Zhang: Mater. Trans. 43 (2002) 1952-1956.

6) X. Y. Li, E. Akiyama, H. Habazaki, A. Kawashima, K. Asami and K. Hashimoto: Corros. Sci. 40 (1998) 1587-1604.

7) P. Y. Park, E. Akiyama, H. Habazaki, A. Kawashima, K. Asami and K. Hashimoto: Corros. Sci. 38 (1996) 1649-1667.

8) J. Bhattarai, E. Akiyama, H. Habazaki, A. Kawashima, K. Asami and K. Hashimoto: Corros. Sci. 40 (1998) 155-175.

9) S. J. Pang, T. Zhang, K. Asami and A. Inoue: Mater. Trans. 42 (2001) 376-379.

10) S. J. Pang, T. Zhang, K. Asami and A. Inoue: Mater. Trans. 43 (2002) 2137-2142.

11) K. Kiuchi, Yamanouchi, M. Kikuchi and Y. Kuriki: Proc. Third Int. Conf. on Nuclear Fuel Reprocessing and Waste Management 2 (1991) 1054.

12) A. Ravi Shankar, R. K. Dayal, R. Balasubramaniam, V. R. Raju, R. Mythili, S. Saroja, M. Vijayalakshmi and V. S. Raghunathan: J. Nuclear Mater. 372 (2008) 277-284.

13) H. Kimura, A. Inoue, S. Yamaura, K. Sasamori, M. Nishida, Y. Shinpo and H. Okouchi: Mater. Trans. 44 (2003) 1167-1171.

14) J. H. Kim, H. Yoshioka, H. Habazaki, A. Kawashima, K. Asami and K. Hashimoto: Corros. Sci. 33 (1992) 1507-1518.

15) A. Kawashima, T. Sato, N. Ohtsu and K. Asami: Mater. Trans. 45 (2004) 131-136.

16) K. Asami and K. Hashimoto: Corros. Sci. 17 (1977) 559-570.

17) K. Asami, K. Hashimoto and S. Shimodaira: Corros. Sci. 17 (1977) $713-723$.

18) K. Asami and K. Hashimoto: Corros. Sci. 24 (1984) 83-97.

19) J. H. Kim, E. Akiyama, H. Habazaki, A. Kawashima, K. Asami and K. Hashimoto: Corros. Sci. 34 (1993) 1947-1955.

20) X. Y. Li, E. Akiyama, H. Habazaki, A. Kawashima, K. Asami and K. Hashimoto: Corros. Sci. 40 (1998) 1587-1604. 